\author{
소 MC1R 우성흑모색 대립인자를 구분하는 변형 프라이머를 \\ 이용한 소 품종들의 유전자형 분포 분석 \\ 한상현* . 김영훈** . 조인철* . 장병귀* . 고문석* . 정하연* . 이성수* \\ 농촌진흥청 국립축산과학원*, 제주특별자치도 축산진흥원**
}

\title{
Analysis of the Genotype Distribution in Cattle Breeds Using a Double Mismatched Primer Set that Discriminates the MC1R Dominant Black Allele
}

\author{
Sang-Hyun Han*, Young-Hoon Kim**, In-Cheol Cho*, Byoung-Gui Jang*, Moon-Suck Ko*, Ha-Yeon Jung* \\ and Sung-Soo Lee* \\ National Institute of Animal Science, RDA, Jeju 690-150, Korea*, \\ Institute for Livestock Promotion, Jeju Special Self-governing Province, Jeju 690-802**
}

\begin{abstract}
With a double mismatch primer set designed for amplifying the modified DNA sequence fragments, bovine melanocortin-1 receptor $(M C 1 R)$ gene encoded in Extension locus which plays a critical role in coat color development was analyzed using polymerase chain reaction mediated restriction fragment length polymorphism (PCR-RFLP). Amplified PCR fragments were successfully discriminated with combining the MspI- and AluI-RFLP into three major alleles $\left(E^{D}, E^{+}\right.$, and $e$ ), directly related to bovine coat color phenotypes. The genotyping results showed that Jeju black cattle contained three $M C 1 R$ alleles, but yellowish-red colored Hanwoo and bridle colored Korean Brindle cattle did not contained the dominant black allele $E^{D}$. However, two dominant black-colored cattle breeds, Holstein and Angus, contained the $E^{D}$ allele over $96 \%$ in frequency. Hanwoo $\times$ Holstein $\mathrm{F}_{1}$ and Hanwoo $\times$ Angus $\mathrm{F}_{1}$ crossbred calves showed $E^{D} / e$ $M C 1 R$ genotypes, and uniformly black coat color. the results suggested that this $M C 1 R$ genotyping method be useful in allele discrimination for bovine $M C 1 R$ gene which used for breed classification and characterization, as one of the important genetic markers, using combination of MspI- and AluI-RFLP for modified PCR product amplified with a newly designed double mismatch primer set.
\end{abstract}

(Key words : Cattle breed, MC1R, Black coat color, Mismatch primer, Genotyping)

\section{I. 서 론}

포유동물의 모색은 멜라닌의 유형과 이를 포 함하는 melanocyte의 분화 및 이동, 분포 양상 에 따라 결정되어 진다. 소의 모색은 품종의
특징을 나타내는 중요한 형질 중 하나로 품종 식별을 위해 이용되는 대표적인 질적 형질 중 하나이다. 우리나라의 재래 소 품종들 역시 모 색을 중심으로 황갈색의 한우, 호반무늬를 나 타내는 칡소, 흑모색의 흑우 등으로 구분되고

Corresponding author : Sung-Soo Lee, Jeju Sub-station, National Institute of Animal Science, RDA, San 175-6 Odeung-dong, Jeju, Jeju 690-150, Korea

Tel : 82-64-754-5710, Fax : 82-64-754-5713, E-mail : lee6470@rda.go.kr 
있다.

포유동물의 모색은 두 가지 색소, 즉 eumelanin (black/brown)과 pheomelanin (yellow/red)의 분포 에 따라 결정되며 이들의 발현은 Extension $(E)$ 와 Agouti (A) 좌위에 의해 주로 조절된다. 다양 한 소 품종에서 $E$ 좌위에 암호화되어 있는 $M C 1 R$ 유전자형에 대한 연구가 보고되었다. 우 성 흑모색은 우성유전자형인 $E^{D}$ 에 의해 발현되 고, 적색 또는 황갈색은 염기결실에 의한 frameshift mutation인 $e$ 가 열성동형접합에서 출 현한다. 또한 야생형인 $E^{+}$는 여러 가지 모색으 로 발현되는 것으로 보고되었다 (Klungland 등, 1995; 이 등, 2000; Rouzaud 등, 2000).

제주흑우는 한우의 황모색과는 확연히 구분 되는 흑모색을 나타내는 특성을 보이나, 개체 나 성장단계에 따라 농도의 차가 관찰되기도 하고, 불분명한 호피문 또는 갈흑색의 모색이 관찰되기도 한다. 반면 외래품종인 Holstein이나 Angus는 제주흑우에 비해 더 짙고 균일한 흑색 을 나타내며 $M C 1 R$ 의 유전자형은 $E^{D}$ 대립인자 의 비율이 월등히 높으며, 한우와 같이 frameshift mutation에 의해 열성동형상태에서 적모색 Holstein이 출현하기도 하는 것으로 알려져 있 다 (Jeorg 등, 1996). 흑모색이 주인 제주흑우의 $M C 1 R$ 유전자형은 세 가지 대립인자 $E^{D}, E^{+}, e$ 에 의한 총 6 가지로 구분되었으나, $E^{D}$ 대립인 자는 제주흑우와 근연인 한우, 칡소, 갈모화우 에서 전혀 관찰되지 않기 때문에 외래 품종 (Holstein 혹은 Angus)과의 교잡에 형성된 것이 며, 야생형 대립인자인 $E^{+}$가 제주흑우 $M C 1 R$ 유전자의 기본형인 것으로 추정하고 있다(이 등, 2000).

소 $M C 1 R$ 유전자의 genotyping은 중합효소연 쇄반응 산물에 대한 제한절편길이다형 (polymerase chain reaction-restriction fragment length polymorphism, PCR-RFLP)에 의한 방법이 고안 되었다. 최근 우리나라에서는 한우와 수입육을 판별하기 위해 $M C 1 R$ 유전자의 다형성을 경제 적이고 신속하게 검출하기 위한 실험기법들이
개발되고 있다. 한우와 수입육의 판별인 경우 한우에서 MC1R e/e 동형접합자를 확인하는 염 기결실 돌연변이의 확인은 $M s p I$ (인지서열 5'-GGCC-3')이나 isoschizomer들에 의해 확인이 용이하며, real-time PCR 등을 이용한 방법들이 이용되고 있다. 반면, $M C 1 R$ 의 $E^{D}$ allele의 확인 은 g.296T>C에 의해 아미노산이 치환된(leucine $>$ valine)형태로, 다형성의 확인을 위해서는 현 재까지 두 가지 제한효소, Acil (5'-CCGC-3') 또 는 MspA1I (5'-CMGCKG-3')를 이용하고 있다 (Rouzaud 등, 2000; 이 등, 2000; 김 등, 2000; 박 등, 2005; Sasazaki 등, 2005; Gan 등, 2007; 도 등, 2007). 하지만 AciI 제한효소의 경우 유 전자 증폭시 이용되는 PCR 반응액에 의해 제 한절단 활성이 저해되어 $\mathrm{PCR}$ 산물을 정제하여 사용해야 하며, 서열 내에 AciI 인지부위가 많 아 전기영동시 고농도의 gel을 활용해야하는 단점을 가지고 있다. 반면 MspA1I의 경우 AciI 제한효소가 갖는 문제점은 해결되나 인지서열 에서 ambiguous code들 $(\mathrm{M}, \mathrm{K})$ 이 출현하는 단점 이 있다. 이에 제주흑우를 비롯한 우리나라의 재래 소 품종들과 외래 소품의 구분에 있어 매 우 중요한 유전자 표지인자로 이용되고 있는 $M C 1 R$ 유전자에서 야생형 대립인자인 $E^{+}$와 Angus나 Holstein 등 외래품종에서 유래한 우성 흑모색 대립인자 $E^{D}$ 를 명확히 구분해 낼 수 있 는 실험기법을 고안하여 제주흑우를 포함한 여 러 소 품종들에서 유전자형의 빈도와 분포를 구명하고자 본 연구를 수행하였다.

\section{ㅍ. 재료 및 방법}

\section{1. 공시동물과 DNA 추출}

본 연구에 이용된 시료는 제주흑우 201두를 제주특별자치도 축산진흥원과 농촌진흥청 국립 축산과학원 제주출장소에서 전혈을 채혈하거나 DNA 상태로 분양받았다. 한우 235 두는 국립축 산과학원과 상기 두 기관에서 채혈하여 DNA 
분리에 이용하였다. 외래 품종 중 $M C 1 R$ 유전 자의 우성 흑모색대립인자 $E^{D}$ 의 빈도가 매우 높은 것으로 알려진 Holstein 107 두와 적모색과 흰색반점의 Red Holstein 3 두, 전신 흑모색 Angus 10 두, 한우 $\times$ Holstein의 $\mathrm{F}_{1} 48$ 두, 한우 $\times$ Angus의 $\mathrm{F}_{1} 4$ 두의 혈액 또는 동결정액을 제주 도내 사육농가와 농협 우유개량사업소에서 수 집하였다. 혈액에서 DNA 분리는 Birren 등 (1997)의 방법을 변형하여 수행하였다. 경정맥 에서 채취한 전혈을 red cell lysis solution을 이 용하여 적혈구를 용해한 후, 회수한 백혈구에 sucrose-proteinase $\mathrm{K}$ nuclei lysis buffer를 첨가하 고 $55^{\circ} \mathrm{C}$ 에서 over-night 진탕하였다. 동결정액에 서 DNA 추출을 위해 $1 \mathrm{mM}$ EDTA/ $0.9 \% \mathrm{NaCl}$ 용액으로 희석한 후 원심분리하여 동결보존액 을 제거하였다. 침강된 정자세포를 Phosphatebuffered saline에 재현탁하고 $0.5 \%$ SDS/ proteinase $\mathrm{K}(10 \mathrm{mg} / \mathrm{ml})$ 용액을 첨가하여 $55^{\circ} \mathrm{C}$ 진 탕항온수조에서 overnight 반응하여 단백질을 제거하였다. 각각의 추출액에 RNase를 처리하 고 phenol-chloroform을 이용하여 단백질층을 분 리 제거한 후, ethanol 침전법으로 $\mathrm{DNA}$ 를 회수 하여 TE buffer에 용해하였다. 준비한 DNA 용 액은 NanoDrop ND-1000 spectrophotometer (NanoDrop Technologies, USA)로 흡광도를 측정 한 후 $\mathrm{A}_{260} / \mathrm{A}_{280} \quad 1.8$ 이상인 DNA 용액들을 $50-60 \mathrm{ng} / \mu l$ 로 희석하여 PCR 증폭을 위한 주형 으로 이용하였다.

\section{2. 이중 mismatch primer의 제작}

소 $M C 1 R$ 유전자형의 분석을 위해 기존에 보 고된 서열 (AF445641)을 이용하여 $E^{D}, E^{+}, e$ 에 해당하는 염기변이 부분을 포함하는 절편을 증 폭하기 위한 primer 쌍을 제작하였다. 우성 흑 모색대립인자형인 MC1R $E^{D}$ (g.296C) 유전자형 의 검출을 위해 기존의 분석법에서 AciI과 MspA1I의 제한절단 부위에 해당하는 염기서열 에서 MC1R g.293T를 A로 변환하여 제한효소
AluI (5'-AGCT-3')의 인지서열로 이용할 수 있는 mismatch primer bMC1RmF(5'-TGG TGA GCG TCA GCA ACG TGC TGG AGA CGG CAG TCA aG-3')을 37번째 염기 $\mathrm{T}$ 를 $\mathrm{A}$ 로 변환하여 제작하였고, $\mathrm{bMC} 1 \mathrm{RmF}$ 와 쌍을 이루며 $\mathrm{PCR}$ 반 응에 이용한 primer bMC1RmR (bMC1mR; 5'TG ATC CGC ACA TGA GCA CGT CGA TGA CAT TGT CCA aC-3') 또한 기존 $M C 1 R$ 유전자 에서 출현하는 AluI 제한효소 인지부위를 제거 하기 위한 37번째 염기 $\mathrm{G}$ 를 $\mathrm{A}$ 로 변환한 이중 mismatch primer 쌍을 제작하였다 (Fig. 1).

\section{3. $\mathrm{PCR}$ 증폭과 $M C 1 R$ 유전자형 결정}

유전자형 결정을 위한 PCR 반응은 $10 \times$ 반응 완충액, $20 \mathrm{mM} \mathrm{dNTP}$, 각각 $200 \mathrm{mM}$ primer, 1.5 units i-Taq DNA polymerase (Intron Biochnology, Korea)와 50-60 ng genomic DNA 용액 에 멸균한 탈이온수를 첨가하고, PTC-200 (MJ Research, USA)을 이용하여 $95^{\circ} \mathrm{C} 3$ 분 초기변성 후, $94^{\circ} \mathrm{C}-30$ 초, $65^{\circ} \mathrm{C}-45$ 초, $72^{\circ} \mathrm{C}-45$ 초로 구성된 연쇄반응을 35 회 반복한 후 $72^{\circ} \mathrm{C}$ 에서 5 분간 최 종 신장하였다. $M C 1 R$ 296T $>C$ 의 결정은 $A l u I$, 311delG (e)는 MspI 제한효소로 공급자의 manual 을 따라 $37^{\circ} \mathrm{C}$ 에서 overnight 처리한 후 $2.5 \%$ agarose gel 상에서 전개하여 판독하였다.

\section{4. 염기서열 결정과 data 분석}

이중 mismatch primer 쌍으로 증폭된 PCR 산 물의 염기서열 결정을 위해 PCR 산물을 Agarose Gel DNA Extraction Kit (Roche, Germany) 로 정제하고 ET dye-termination sequencing kit (Amersham Pamacia, USA) 반응 후 MegaBase1000 (Amersham Pamacia, USA)을 이용하여 확인하였 다. 염기변이 확인은 본 연구에서 결정된 서열 들과 기존에 GenBank database에 등록된 소 MC1R 유전자 서열들(NM_174108, EU169232-4, $\mathrm{AF} 445641-2)$ 과 다중정렬하여 비교하였다 (Fig. 1). 
MClRmF 5'-TGGT GAGCGTCAGC AACGTGCTGG AGACGGCAGT CAaG-3' 260

280

300

320

MC1R ED: ACTTGCTGGT GAGCGTCAGC AACGTGCTGG AGACGGCAGT CATGCCGCTG CTGGAGGCCG GTGTCCTGGC MC1R $E^{+}$: ACTTGCTGGT GAGCGTCAGC AACGTGCTGG AGACGGCAGT CATGCTGCTG CTGGAGGCCG GTGTCCTGGC $M C 1 R$ e : ACTTGCTGGT GAGCGTCAGC AACGTGCTGG AGACGGCAGT CATGCTGCTG CTGGAGGCC- GTGTCCTGGC

$$
340 \quad 360 \quad 380
$$

MC1R ED: CACCCAGGCG GCCGTGGTGC AGCAGCTGGA CAATGTCATC GACGTGCTCA TCTGCGGATC CATGGTGT

MC1R $E^{+}:$CACCCAGGCG GCCGTGGTGC AGCAGCTGGA CAATGTCATC GACGTGCTCA TCTGCGGATC CATGGTGT

$M C 1 R$ e : CACCCAGGCG GCCGTGGTGC AGCAGCETGGA CAATGTCATC GACGTGCTCA TCTGCGGATC CATGGTGT GTTGGA CAATGTCATC GACGTGCTCA TCTGCGGATC CA

MC1RmR 5'-TG GATCCGCACA TGAGCACGTC GATGACATTG TCCAaC-3'

Fig. 1. Sequence alignment of three $M C 1 R$ alleles and nucleotide sequences of the mismatch primers used in this study. Bold letters indicate polymorphic nucleotides corresponding to g.296T>C and g.310delG, respectively. Underlined letters are modification target nucleotides for mismatch primers. Small letters are mismatched sequences of modified primers.

\section{III. 결과 및 고찰}

소의 모색 발현에 결정적인 역할을 수행하는 $M C 1 R$ 유전자형을 변형된 염기서열이 증폭하 게 짜여진 이중 mismatch primer 쌍을 이용하여 증폭한 후 RFLP 방법으로 분석하였다. 제주흑 우와 칡소, 한우를 포함한 소 5 품종, 한우 $\times$ Holstein $\mathrm{F}_{1}$, 한우 $\times$ Angus $\mathrm{F}_{1}$ 에서 $M C 1 R$ 의
g.296T>C와 g.310delG에 의해 형성된 Extension 좌위의 세 가지 대립인자 $E^{D}, E^{+}, e$ 가 모두 검 출되었다(Fig. 2). 기존의 연구 보고에서 AciI이 나 MspA1I에 의해 구분되었던 $M C 1 R$ 296C $\left(E^{D}\right)$ 와 $296 \mathrm{~T}\left(E^{+}\right.$또는 $\left.e\right)$ 는 mismatch priming에 의해 증폭된 PCR 산물에 대한 AluI-RFLP를 통해 성 공적으로 구분되었고(Fig. 2A), 열성 대립인자 인 $e$ 역시 MspI-RFLP에 의해 $E^{D}, E^{+}$등과 구분

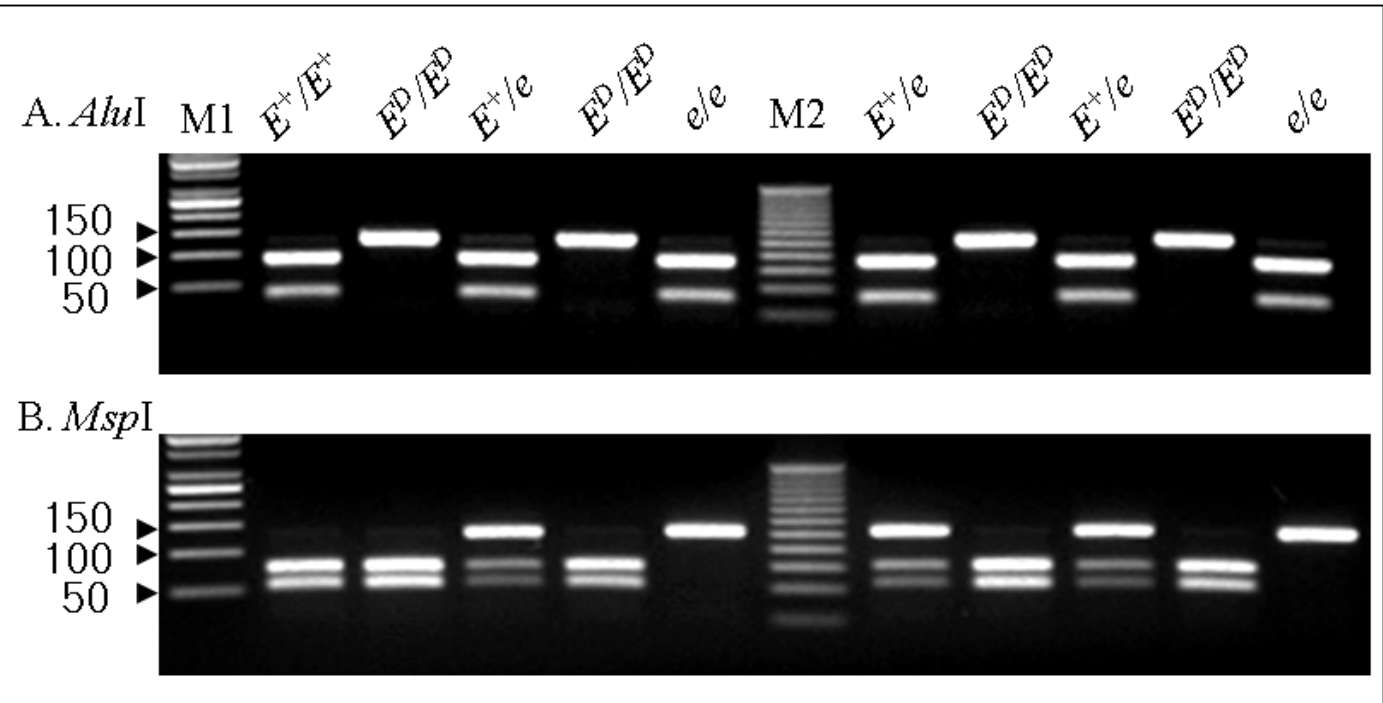

Fig. 2. Genotyping of three alleles for $M C 1 R$ gene using the modified mismatch primer set designed in this study. PCR products were digested by Alul (A) and Mspl (B). Digested fragments were separated on $2.5 \%$ agarose gels with two molecular markers(M1 and M2 are 50-bp and 100-bp DNA ladder, respectively). 
되었다(Fig. 2B). Table 1은 조사에 이용한 소 품종별 $M C 1 R$ 유전자형의 분포와 품종 내 빈도 를 나타낸 것이다.

분석결과 조사에 이용한 5 품종에서 모두 기 존의 연구와 유사한 결과를 보였다. 먼저 한우 에서 가장 높은 빈도를 차지하는 열성대립인자 $\mathrm{e}$ 는 해당하는 $M C 1 R$ g.310delG 염기결실은 전 신 흑색인 Angus를 제외한 모든 품종에서 관찰 되었다. 반면, e/e 동형접합자는 황색인 한우 품 종과 모색이 적-백 얼룩인 Red Holstein 2 두 에서만 관찰되었고, Red Holstein 중 1 두는 $E^{+} / e$ 의 $M C 1 R$ 유전자형을 나타내었다. 흑-백 얼룩 인 Black Holstein은 $E^{D /}$ - 형태로 $E^{D} / E^{D}$ 가 대부 분이며 $E^{D} / E^{+}$와 $E^{D} / e$ 는 각각 1 두에서만 확인되 었다. 황색 한우와 1 대 교잡 $\left(\mathrm{F}_{1}\right)$ 에서는 한우 $\times$ Holstein $\mathrm{F}_{1}$ 과 한우 $\times$ Angus $\mathrm{F}_{1}$ 에서 모두 $E^{D} / e$ 만 확인되었으며, 이들의 모색은 얼굴이나 등 부 위에 얼룩이 없는 흑색을 나타내었다.

유전자분석기법의 도입은 범인식별, 친자감 별뿐만 아니라 학술적 연구에서도 data의 정확 성이 매우 중대하게 다루어져야 하며, 분석과 정 역시 신속성과 경제성이 동시에 요구된다. 축산업에 있어 품종의 식별은 다양한 분야에서 요구되는 필수조건이며, 그 중 우리나라에서 중요 경제축종으로 다루어지는 한우는 유통과 정에서 타 품종과의 정확한 식별은 유통구조의
확립과 농가소득 보존의 전제조건이 되고 있 다. 현재까지 유전자 수준의 다형성을 이용하 여 한우와 수입육, 특히 젖소에 대한 품종구분 을 수행하고자하는 다양한 연구 결과들이 보고 되었다.

핵산지문법을 이용한 한우 판별이 시도된 이 래 (이 등, 1994; 이와 오, 1995), 한우와 수입육 의 식별을 위한 유전자 분석은 다양한 방법으 로 전개되어왔다. 이 등 (2000)이 한우를 포함한 제주흑우, 일본화우 등에서 모색과 연관된 유 전자인 $M C 1 R$ 의 유전자형의 보고에서 한우와 젖소육의 구분가능성을 제시한 이래, 한우와 수입육 구분은 황모색 한우의 유전자형과 우성 흑모색인 Holstein, Angus 등과의 구분에 초점 이 맞추어져왔다. 정 등 (2000)은 한우와 Angus, Holstein, Hereford, Charolais 등에 대한 $M C 1 R$ $\mathrm{RFLP}$ 연구에서 MC1R310delG의 확인을 통한 한우와 수입육의 판별 가능성을 제기하였고, 김 등 (2000)이 한우를 포함한 Brown Swiss, Limousin, Simmental 등의 황모색 소 품종과 흑 모색 품종, 수입육에 대한 연구에서 $M C 1 R$ 열 성대립인자의 동형접합체의 빈도가 한우 품종 에서 가장 높은 빈도를 갖는 것으로 보고하였 다. 이는 비슷한 황모색을 보이는 외국 소 품 종들보다 더 높은 빈도였으며, 이를 바탕으로 한우와 타 품종의 구분에 있어 $M C 1 R$ 유전자형

Table 1. Genotype and allele frequencies of $M C 1 R$ gene in cattle breeds

\begin{tabular}{|c|c|c|c|c|c|c|c|c|c|c|}
\hline \multirow[b]{2}{*}{ Breed } & \multirow{2}{*}{$\begin{array}{l}\text { No. of } \\
\text { animals }\end{array}$} & \multicolumn{6}{|c|}{ Genotype } & \multicolumn{3}{|c|}{ Allele } \\
\hline & & $E^{D} / E^{D}$ & $E^{D} / E^{+}$ & $E^{D} / e$ & $E^{+} / E^{+}$ & $E^{+} / e$ & e/e & $E^{D}$ & $E^{+}$ & $e$ \\
\hline Hanwoo & 235 & - & - & - & - & 20 & 215 & 0.000 & 0.043 & 0.957 \\
\hline Jeju Black cattle & 201 & - & 43 & 12 & 68 & 78 & - & 0.137 & 0.639 & 0.224 \\
\hline Korean Brindle cattle & 17 & - & - & - & 4 & 13 & - & 0.000 & 0.618 & 0.382 \\
\hline Holstein & 110 & 105 & 1 & 1 & - & $1^{*}$ & $2 *$ & 0.964 & 0.009 & 0.027 \\
\hline Angus & 10 & 10 & - & - & - & - & - & 1.000 & 0.000 & 0.000 \\
\hline Hanwoo $\times$ Holstein $F_{1}$ & 48 & - & - & 48 & - & - & - & 0.500 & 0.000 & 0.500 \\
\hline Hanwoo $\times$ Angus $F_{1}$ & 4 & - & - & 4 & - & - & - & 0.500 & 0.000 & 0.500 \\
\hline
\end{tabular}

Numbers in parentheses indicate the numbers of allele or animal detected.

* showed red coat color with white spots but not black hairs. 
의 확인은 품종식별을 위한 유전자 분석의 출 발점이 되고 있다. 정 등 (2001)은 MC1R 유전 자의 증폭산물을 $M s p I$ 으로 제한 절단한 후 single stranded conformation polymorphism 방식 으로 확인하는 방식을 제안하였고, 김 등 (2004) 는 MC1R g.310delG와 선별적으로 결합하는 3‘-tailed primer를 이용한 흑모색 소 품종 대비 한우 판별법을 제안하였다. 박 등 (2005)은 PCR 증폭과정에서 대립인자-특이적인 탐침의 부착 여부에 따라 판독하는 real-time PCR 기법을 소 개하였으며, 김과 이(2005)는 역시 $M C 1 R$ g.310delG에 대한 RFLP를 통하여 한우, Holstein, 한우 $\times$ Holstein의 교잡 $\mathrm{F}_{1}$ 인 먹우의 구 분이 가능함을 제시하였고, 고(2005)는 $M C 1 R$ 유전자에서 multiplex PCR을 이용한 한우육과 젖소육의 구분을 소개하였다. 하지만, $M C 1 R$ 유 전자형의 분석은 모색과 연관된 유전자라는 차 원에서는 높은 신뢰성을 나타내지만 한우의 일

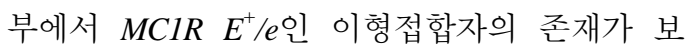
고되었으며, 일본의 화우와 중국의 소 재래소 품종에서도 유사한 결과가 확인되어 (이 등, 2000,2002 ; 김 등, 2000 ; 정 등, 2000,2001 ; Sasazaki 등, 2005; Gan 등, 2007), 단일 유전자 분석을 통한 품종 식별에는 어느 정도의 위험 이 따른다고 하겠다. 이를 보완하기 위해 유전 체 상에 많이 산재되어 있는 microsatellite에 대 한 유전자 분석법의 도입이나 한우 특이 SNP 를 발굴하여 분석체계 내로 도입되어야 할 것 으로 사료된다.

한우 $(M C 1 R \quad e / e)$ 와는 달리 제주흑우와 칡소 는 $E^{+}$/-가 가장 많은 빈도를 나타내어 $\mathrm{SNP}$ 차 원에서 볼 때 열성 황모색대립인자 $e$ 뿐만 아 니라 야생형 대립인자 $E^{+}$와 우성 흑모색대립인 자 $E^{D}$ 에 대한 식별이 무엇보다도 중요한 선결 조건임을 보여주고 있다. 제주흑우의 경우 연 구보고에서 낮은 빈도이긴 하나 $E^{D}$ 가 출현하며 이는 Holstein, Angus 등 외국 소 품종과의 교 잡에 의해 유입된 것으로 추정하고 있으며 점 진적으로 제거해야할 것으로 제안되었다(이
등, 2000). 본 연구에서 분석한 결과에서도 제 주흑우에서 아직까지 $E^{D}$ /를 보유한 개체들이 다소 확인되었으며, 개체의 이력을 추적한 결 과, 과거 후보축 수집과정에서 유입된 경우와 그들의 직계후손에서 출현함으로 알 수 있었 다. 대립인자 $E^{D}$ 의 빈도는 과거에 비해 많이 감소되어 있음을 확인할 수 있었으나, 품종의 특성을 명확히 유지하기 위해서 $E^{D}$ 보유 개체 의 제거가 빠른 시일 내에 완료되어야 할 것으 로 사료된다. 칡소는 제주흑우, 한우와는 달리 이형접합자인 $E^{+} / e$ 가 기본형이며, $E^{+} / E^{+}$개체 역시 보고되었다(이 등, 2002). 현재의 칡소 계 통 내에 Holstein이나 Angus 등의 $E^{D}$ 대립인자 형이 유입되지 않았다는 점에서 다행스러운 결 과라 할 것이며, 향후 $E^{D}$ 유전자형의 유입을 차단하는 것은 중요한 과제가 될 것으로 사료 된다.

기존에 보고된 $M C 1 R$ 유전자의 $E^{D}$ 유전자형 과 $E^{+}$유전자형의 구별 방법 중 해당 염기변이 서열을 직접 확인하는 방법으로는 제한효소 AciI과 MspA1I을 이용한 PCR-RFLP 방식이 보 편적으로 이용되고 있다. 연구보고들에서 AciIRFLP에서는 PCR 반응액에 의한 영향을 받아 추후 정제과정을 거쳐야 한다는 점 (Sasazaki 등, 2005)과 $M C 1 R$ 유전자 서열 내에서 다소 많은 인지부위를 포함하고 있어 해석상의 오류 가 발생할 수 있다. 또한 MspA1I-RFLP는 인지 서열 중 두 개의 ambiguous code $(\mathrm{M}=\mathrm{A}$ 또는 $\mathrm{C}$, $\mathrm{K}=\mathrm{G}$ 또는 $\mathrm{T}$ )가 있어 해당부위에서 제한절단에 영향을 줄 수 있는 또 다른 염기변이에 의한 오류 요인이 잠재되어 있다. 비록 현재까지는 해당부위에 변이보고는 다행히 없으나 그 가능 성을 완전히 배제할 수 없다. $E^{D}$ 와 $E^{+}$를 구분 하는 g.296T $>C$ 가 ambiguous code상에 존재하기 때문에 보다 명확한 분석법의 도입이 필요하다 고 하겠다. 이외에도 유전자형의 분석을 위해 제한효소 구매와 고농도의 gel 제조와 확인에 소요되는 경제적 측면도 무시할 수 없다. 뿐만 아니라, PCR-RFLP 방식은 분자유전학과 관련 
한 연구실에 보편적으로 보급되어 있는 일반적 인 PCR 기기와 간단한 agarose gel 전기영동 장 치만으로 확인할 수 있어 고가의 특수장비 없 이 분석할 수 있는 효율성을 함께 고려한다면, 본 연구에서 고안한 이중 mismatch primer 쌍의 활용을 통한 AluI-RFLP 분석법은 현재 소의 품 종 특성 규명과 품종 식별에서 가장 중요한 유 전자 중 하나인 $M C 1 R$ 유전자의 세 가지 대립 인자를 식별하는 데 유용한 실험기법이 될 것 이며, 품종 식별을 위한 자료 제공에 효율적으 로 이용될 수 있을 것으로 사료된다.

\section{IV. 요 약}

소의 모색 발현에 결정적인 역할을 수행하며 Extension 좌위에 암호화되어 있는 melanocortin1 receptor $(M C 1 R)$ 유전자형을 변형된 염기서열 이 증폭되게 제작된 이중 mismatch primer 쌍을 이용하여 PCR-RFLP 방법으로 분석하였다. 증 폭된 PCR 절편들은 $M C 1 R$ 유전자에서 모색 표 현형과 직접적으로 연관되어 있어 중요하게 다 루어지고 있는 세 가지 대립인자들 $\left(E^{D}, E^{+}, e\right)$ 로 $M s p I-$ 과 $A l u I-R F L P$ 에 의해 성공적으로 구분 되었다. $M C 1 R$ 유전자형의 분포를 조사한 결과 제주흑우는 세 가지 대립인자가 모두 출현하였 고, 황-적모색의 한우와 호피문의 칡소에서는 흑모색우성 대립인자 $E^{D}$ 가 출현하지 않았다. 반면, 우성흑모색으로 알려진 두 소 품종 Holstein과 Angus는 $E^{D}$ 대립인자의 빈도가 $96 \%$ 이상으로 조사되었다. 한우 $\times$ Holstein $\mathrm{F}_{1}$ 과 한우 $\times$ Angus $\mathrm{F}_{1}$ 은 모두 $E^{D} / e$ 의 유전자형을 나타내었 고, 표현형은 전신 흑색으로 확인되었다. 본 연 구에서 고안한 이중 mismatch primer 쌍을 이용 한 $M C 1 R$ 유전자 증폭 절편에 대한 $M s p I-$ 과 AluI-RFLP 조합은 소의 품종 특성 규명과 품종 식별에서 매우 중요한 유전자 표지인자 중 하 나인 $M C 1 R$ 유전자의 세 가지 대립인자를 식별 하는 데 유용한 실험기법이 될 것으로 사료된 다.

$$
\mathrm{V} \text {. 사 사 }
$$

본 연구는 2008년도 농촌진흥청 박사후연수 과정지원사업에 의해 이루어진 것이며 연구비 지원에 감사드립니다.

\section{VI. 인 용 문 헌}

1. Gan, H., Li, J., Wang, H., Gao, Y., Liu, W., Li J. and Zhong, J. 2007. Allele frequencies of TYR and $M C 1 R$ in Chinese native cattle. Anim. Sci. J. 78:484-488.

2. Joerg, H., Fries, H. R., Meijerink, E. and Stranzinger, G. F. 1996. Red coat color in Holstein cattle is associated with a deletion in the MSHR gene. Mamm. Genome 7(4):317-318.

3. Klungland, H., Vage, D. I., Gomez-Raya, L., Adalsteinsson, S. and Lien, S. 1995. The role of melanocyte-stimulating hormone (MSH) receptor in bovine coat color determination. Mamm. Genome 6: 636-639.

4. Rouzaud, F., Martin, J., Gallet, P. F., Delourme, D., Goulemot-Leger, V., Amigues, Y., Ménissier, F., Levéziel, H., Julien, R. and Oulmouden, A. 2000. A first genotyping assay of French cattle breeds based on a new allele of the extension gene encoding the melanocortin-1 receptor (Mc1r). Genet. Sel. Evol. 32(5):511-20.

5. Sasazaki, S., Usui, M., Mannen, H., Hiura, C. and Tsuji, S. 2005. Allele frequencies of the extension locus encoding the melanocortin-1 receptor in Japanese and Korean cattle. Anim. Sci. J. 76: 129-132.

6. 고바라다. 2005. Multiplex allele specific PCR 방 법을 이용한 한우고기와 젖소고기의 신속한 판 별. 대한수의학회지 45(3): 351-357.

7. 김태중, 이재일. 2005. MC1R 유전자의 PCRRFLP를 이용한 한우육과 젖소육/black Angus 수 입육의 구분. 대한수의학회지 45(3):335-339.

8. 김태헌, 윤두학, 박응우, 이혜영, 오성종, 정일정, 탁태영, 김경남, 한재용. 2000. 소 품종별 Melanocortin Receptor $1(M C 1 R)$ 유전자의 유전자 
형 빈도에 관한 연구. 한국동물자원과학회지 42: 735-744.

9. 도경탁, 신희영, 이종혁, 김내수, 박응우, 김관석. 2007. 한우에서의 모색관련 유전자 변이에 관한 연구. 한국동물자원과학회지. 49(6):711-718.

10. 박성도, 김태중, 이재일. 2005. 모 모색관련 MC1R 유전자의 SNP와 관련한 MGB probe에 기 초한 real-time PCR을 이용한 한우육과 Holstein 육의 판별. 대한수의학회지. 45(1):25-28.

11. 이창수, 오홍록. 1995. PCR법을 이용한 쇠고기의 성판별과 근육부위별 한우와 젖소의 DNA 다형 성 분석. 한국축산식품학회지 15(1):26-30.

12. 이창수, 유영복, 나기준, 조병대, 최병규. 1994. 핵산지문법에 의한 한우의 판별. 한국동물자원과 학회지. 36:369-373.

13. 이성수, 양보석, 양영훈, 고서봉, 정진관, 오운용, 오성종, 김규일. 2002. 칡소와 비경흑색 한우의
Melanocortin Receptor 1(MC1R) 유전자형 분석. 한국동물자원과학회지 44(1):23-30.

14. 이성수, 양영훈, 강승률, 오운용, 양보석, 고서봉, 오성종, 김규일. 2000. 한우, 제주재래흑우, 흑모 화우와 갈모화우에서의 $\mathrm{MSH}$ Receptor $(M C 1 R)$ 유전자의 유전자형 및 빈도 분석. 한국동물자원 과학회지 42(3):253-260.

15. 정의룡, 김우태, 김연수, 한상기. 2000. 소 모색관 련 유전자 $M C 1 R$ 의 PCR-RFLP Marker를 이용한 한우육 판별. 한국동물자원과학회지 42(4):379390.

16. 정의룡, 김우태, 김연수, 한상기. 2001. PCR$\mathrm{SSCP}$ 기법을 이용한 소 MC1R 유전자의 다형성 분석 및 한우육 감별. 한국동물자원과학회지 43 (1):45-52.

(접수일자 : 2008. 8. 20. / 수정일자 : 2008. 10. 20./ 채택일자 : 2008. 10. 22.) 